\title{
Analysis on the Influence of Price, Product, and Advertisement on the Purchasing Decision of Indomie Instant Noodle
}

\author{
Vincent Rivaldi Kosasih ${ }^{1^{*}} \quad$ Li Dong Sheng $^{2} \quad$ Bi Zhan Tian ${ }^{3}$ \\ Department of International Business and Management, \\ Zhejiang University of Science \& Technology, Hangzhou. PR, CN. \\ vincent5rk@gmail.com
}

\begin{abstract}
This study aims to determine and analyze the influence of price, advertisement, and product quality on Indomie instant noodle purchasing decisions. The researcher collects the data online in the city of Jakarta. Due to limited time and money, some of the existing populations were taken to be the sample in the study. Due to limited time and funds, the researcher determined the number of samples in this study as many as 200 respondents. Data were collected by spreading the questionnaires online by using Google Form, the variables studied were using a Likert scale. The list of questions was first tested using validity and reliability testing, then analysed by classic assumption test and hypothesis test using SPSS software. Simultaneously, the variables of price, advertisement, and product quality have a significant effect on the purchasing decision of Indomie instant noodles.
\end{abstract}

Keywords: Price, Advertisement, Product, Purchasing Decision

DOI: $10.7176 / \mathrm{JESD} / 12-6-03$

Publication date:March $31^{\text {st }} 2021$

\section{Introduction}

Nowadays, the development of food substitution products is going faster. One of them is instant noodles which is a substitute product which is of great interest in Indonesia and also in some other countries. Some students live in the dorm, most of their main income comes from their parents every month, because they don't have steady income. So here, the behavior of consuming instant noodles is very common, considering instant noodles are products that are quite affordable. People's habit of consuming this food products is also influenced by people's lifestyles that are more dynamic due to the demands of work or customers are higher. People prefer fast and easy serving food like instant noodles to support their mobility. Because of this, instant noodles in Indonesia are increasing in demand. Instant noodle is one of the most practical, quick, and delicious foods ever, and most of the people in this world love to eat instant noodle. Moreover, instant noodles become the solution in overcoming the problem of hunger in the world. With the high demand for instant noodles in Indonesia emerged several brands of instant noodles, such as Indomie, Mie Sedaap, Supermi and Sarimie instant noodles. They compete with each other in terms of taste, packaging, price, and even promotion to attract consumers in making purchasing decisions. Indonesian brand instant noodle "Indomie" is one of the most popular instant noodles in the world, even become the favourite one in some countries.

Purchasing decisions are the characteristics of the buyer and the process. Decision making will lead to purchase decisions. Factors that need to be considered by producers when consumers make purchases such as product quality, prices and advertisement made by producers of a product to attract the attention of consumers to make a purchase. Indomie is a brand of instant noodle products that is very popular in Indonesia, which is produced by PT. Indofood CBP Sukses Makmur. The success of the Indomie brand instant noodles in achieving the position of market leader is inseparable from the factors that influence consumers to make purchases. These factors are product quality, price, and advertisement. This research purpose is to determine how product quality, price and advertisement affect the purchasing decisions of instant noodle products of brand "Indomie". This research is to increase theoretical knowledge and broaden the knowledge of marketing management in the field of instant noodles and apply theories obtained from lectures. Instant Noodle is a product that is preferred by consumers because of its practicality. Therefore, it is necessary for companies to analyze the consumer behavior of these products to find out their purchasing patterns. The research is expected to be beneficial for the company for information material and can understand how the influence of product quality, price and promotion on purchasing decisions.

\section{Research Methodology}

This research was conducted using a survey approach, the survey approach is the activity of collecting as much data as possible regarding the facts that are supporting the research, with the aim of knowing the status, symptoms of determining the similarity of status by comparing with the standards that have been selected and / or determined. The data collection method used in this study was a questionnaire method. The questionnaire method in its form is based on self-report or at least on personal knowledge and beliefs. The assumption held by the researcher in using this method is that the research subject is the person who knows best about himself and that the subject 
statement given to the researcher is true and reliable. Due to limited time and money, some of the existing populations were taken to be the sample in the study. Due to limited time and funds, the researcher determined the number of samples in this study as many as 200 respondents.

Data collection was done by using questionnaires to respondents regarding:

1. Questions about the identity of the respondent, which consists of several questions consisting of name, age, gender, and education. This question is used to analyze the answers given by respondents to closed questions, because the level of education will be an important factor in answering closed questions.

2. Questions regarding a series of data relating to product excellence and customer understanding. Questions in closed questions are made referring to the Likert Scale, where each is made using a scale of $1-5$ in order to obtain interval data and are given a score as follows:

1: Strongly disagree

2: Disagree

3: Neither agree nor disagree

4: Agree

5: Strongly agree

\subsection{Data Analysis Method}

In this study, researchers used multiple regression analysis according to Malhotra (2010: 577) is a statistical technique that simultaneously develops a mathematical relationship between two or more independent variables and the dependent variable. In this study, the SPSS program was used to process and analyze research data, namely the validity test, reliability test, normality test, multicollinearity test and heteroscedasticity test. The regression model used in this study is multiple regression to test the $t$ test, $f$ test and the coefficient of determination.

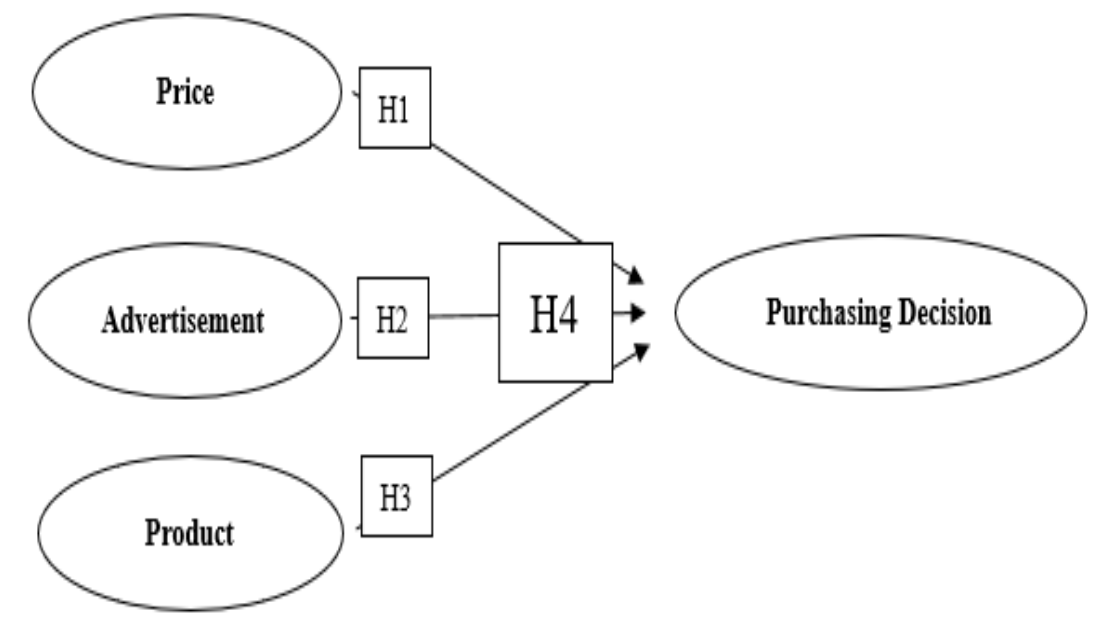

\subsection{Research Model and Hypothesis}

Based on the theoretical framework mentioned above, it can be argued that through price, advertisement, and product variables either partially or simultaneously it is suspected that it has an influence on the purchasing decision of instant noodle products. Then the hypothesis can be proposed as follows:

H1: Price variable has influence on the purchasing decision of instant noodle.

H2: Advertisement variable has influence on the purchasing decision of instant noodle.

H3: Product variable has influence on the purchasing decision of instant noodle.

H4: Price, Advertisement, and Product variables have influence on the purchasing decision of instant noodle.

\section{Research Results and Discussions}

\subsection{Descriptive Analysis}

Data obtained from the results of descriptive analysis, shows the highest value (maximum), lowest value (minimum), average (mean) and standard deviation of each variable under study for the hypothesis, the independent variables are price, advertisement, product, and the dependent variable is the purchasing decision. The result of descriptive analysis is stated on the table below. 


\begin{tabular}{lrrrrr|r} 
& \multicolumn{2}{c}{ Table 1: Descriptive Statistics } & & \\
& $N$ & \multicolumn{1}{c}{ Minimum } & Maximum & Mean & Std. Deviation \\
\hline Price & 200 & 6 & 15 & 11.06 & 1.899 \\
\hline Advertisement & 200 & 8 & 25 & 19.40 & 3.140 \\
\hline Product & 200 & 11 & 25 & 19.62 & 2.627 \\
\hline Decision & 200 & 8 & 20 & 15.94 & 2.104 \\
\hline Valid N (listwise) & 200 & & & & \\
\hline
\end{tabular}

From the table above, it's stated that the mean of X1 variable (price) is 11.06 , maximum is 15 and minimum is 6 , with the standard deviation of 1.899 . The mean of X2 variable (advertisement) is 19.40, maximum is 25 , and minimum is 8 , with the standard deviation of 3.140. The mean of X3 variable (product) is 19.62, maximum is 25 , and minimum is 11, with the standard deviation of 2.627. The mean of Y Variable (purchasing decision) is 15.94, maximum is 20 , and minimum is 8 , with the standard deviation of 2.104 .

\subsection{Validity Test}

Price Variable Validity Test Result

According to the table above, the results obtained from testing the instrument variable price as a whole have a Corrected Item Total Correlation value that is greater than 0.30 , so thus it can be concluded that all statement instruments of the price variable used are valid and this instrument can be used in research, this is also reinforced by the significance value (2-tailed) which is entirely below 0.05 .

Table 2: Correlations

\begin{tabular}{|c|c|c|c|c|c|}
\hline & & item1 & item2 & item3 & total \\
\hline \multirow[t]{3}{*}{ item1 } & Pearson Correlation & 1 & $.146^{\circ}$ & .128 & $.810^{*}$ \\
\hline & Sig. (2-tailed) & & .039 & .071 & .000 \\
\hline & $\mathrm{N}$ & 200 & 200 & 200 & 200 \\
\hline \multirow[t]{3}{*}{ item2 } & Pearson Correlation & $.146^{\circ}$ & 1 & .007 & $.407^{*}$ \\
\hline & Sig. (2-tailed) & .039 & & .925 & .000 \\
\hline & $\mathrm{N}$ & 200 & 200 & 200 & 200 \\
\hline \multirow[t]{3}{*}{ item3 } & Pearson Correlation & .128 & .007 & 1 & $.604^{*}$ \\
\hline & Sig. (2-tailed) & .071 & .925 & & .000 \\
\hline & $\mathrm{N}$ & 200 & 200 & 200 & 200 \\
\hline \multirow[t]{3}{*}{ total } & Pearson Correlation & $.810^{* *}$ & $.407^{*}$ & $.604^{*}$ & 1 \\
\hline & Sig. (2-tailed) & .000 & .000 & .000 & \\
\hline & $\mathrm{N}$ & 200 & 200 & 200 & 200 \\
\hline
\end{tabular}

**. Correlation is significant at the 0.01 level (2-tailed).

\section{Advertisement Variable Validity Test Result}

Table 3: Correlations

According to the table above, the results obtained from testing the instrument variable price as a whole have a Corrected Item Total Correlation value that is greater than 0.30 , so thus it can be concluded that all statement instruments of the advertisement variable used are valid and this instrument can be used in research, this is also reinforced by the significance value (2-tailed) which is entirely below 0.05 . 
Product Variable Validity Test Result

Table 4: Correlations

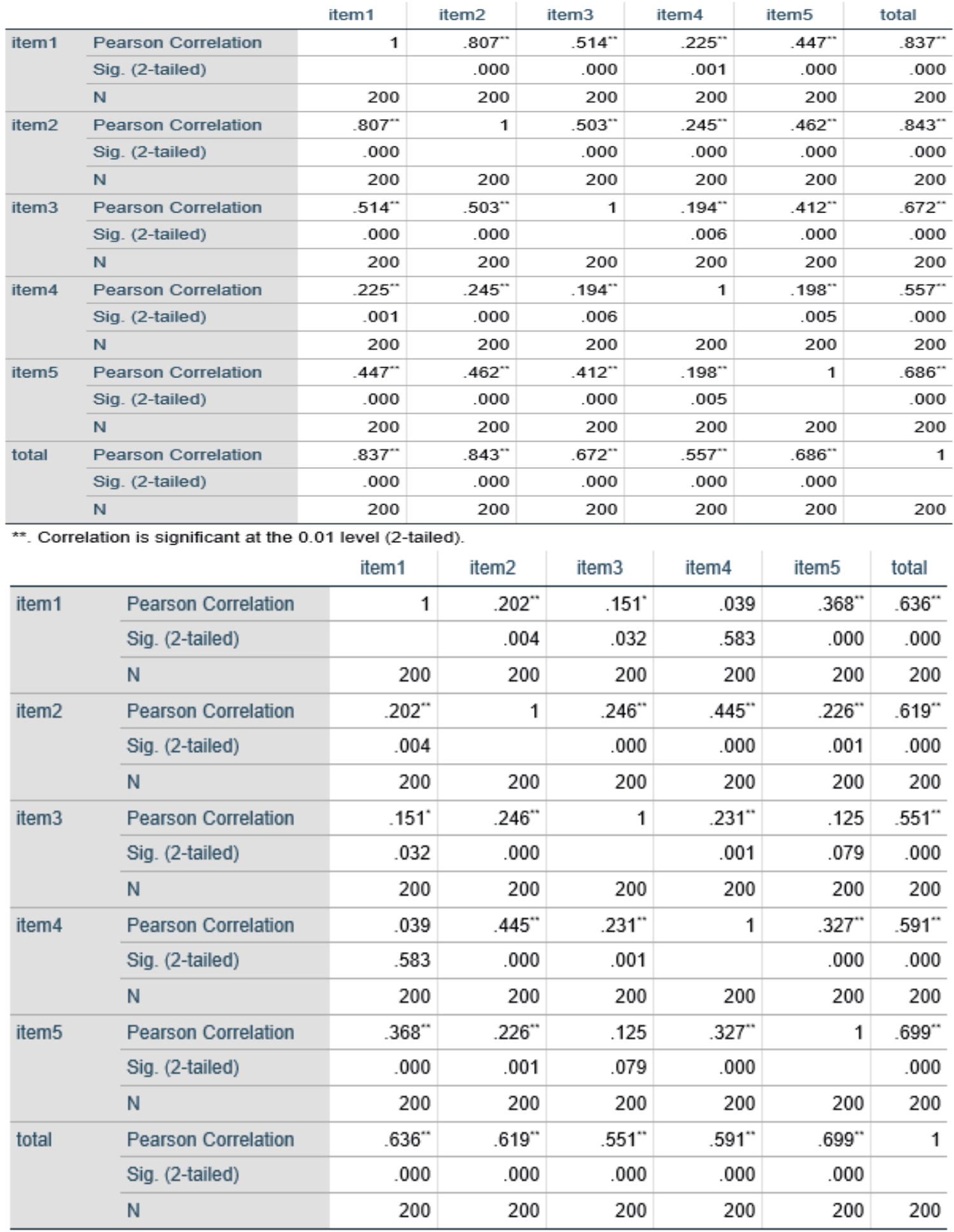

**. Correlation is significant at the 0.01 level (2-tailed).

*. Correlation is significant at the 0.05 level (2-tailed).

According to the table above, the results obtained from testing the instrument variable price as a whole have a Corrected Item Total Correlation value that is greater than 0.30, so thus it can be concluded that all statement instruments of the product variable used are valid and this instrument can be used in research, this is also reinforced by the significance value (2-tailed) which is entirely below 0.05 . 
Purchasing Decision Variable Validity Test Result

Table 5: Correlations

\begin{tabular}{|c|c|c|c|c|c|c|}
\hline & & tem 1 & item2 & item3 & item4 & total \\
\hline \multirow[t]{3}{*}{ item1 } & Pearson Correlation & 1 & .063 & $.289^{*}$ & $.294^{* *}$ & $.709^{*}$ \\
\hline & Sig. (2-tailed) & & .372 & .000 & .000 & .000 \\
\hline & $\mathrm{N}$ & 200 & 200 & 200 & 200 & 200 \\
\hline \multirow[t]{3}{*}{ item2 } & Pearson Correlation & .063 & 1 & -.087 & -.081 & $.557^{*}$ \\
\hline & Sig. (2-tailed) & .372 & & .220 & .252 & .000 \\
\hline & $\mathrm{N}$ & 200 & 200 & 200 & 200 & 200 \\
\hline \multirow[t]{3}{*}{ item3 } & Pearson Correlation & $.289^{*}$ & -.087 & 1 & $.487^{\circ}$ & $.543^{*}$ \\
\hline & Sig. (2-tailed) & .000 & .220 & & .000 & .000 \\
\hline & $\mathrm{N}$ & 200 & 200 & 200 & 200 & 200 \\
\hline \multirow[t]{3}{*}{ item4 } & Pearson Correlation & $.294^{*}$ & -.081 & $.487^{*}$ & 1 & $.545^{*}$ \\
\hline & Sig. (2-tailed) & .000 & .252 & .000 & & .000 \\
\hline & $\mathrm{N}$ & 200 & 200 & 200 & 200 & 200 \\
\hline \multirow[t]{3}{*}{ total } & Pearson Correlation & $.709^{*}$ & $.557^{*}$ & $.543^{*}$ & $.545^{*}$ & 1 \\
\hline & Sig. (2-tailed) & .000 & .000 & .000 & .000 & \\
\hline & $\mathrm{N}$ & 200 & 200 & 200 & 200 & 200 \\
\hline
\end{tabular}

**. Correlation is significant at the 0.01 level (2-tailed).

According to the table above, the results obtained from testing the instrument variable price as a whole have a Corrected Item Total Correlation value that is greater than 0.30 , so thus it can be concluded that all statement instruments of the purchasing decision variable used are valid and this instrument can be used in research, this is also reinforced by the significance value (2-tailed) which is entirely below 0.05 .

4.3 Reliability Test

Table 6: Reliability Test Result

\begin{tabular}{|l|l|c|c|c|}
\hline & \multicolumn{1}{|c|}{ Statement } & Cronbach's Alpha & N Of Items & Result \\
\hline 1 & Price variable & 0.677 & 3 & Reliable \\
\hline 2 & Advertisement variable & 0.775 & 5 & Reliable \\
\hline 3 & Product variable & 0.652 & 5 & Reliable \\
\hline 4 & Purchasing decision variable & 0.689 & 4 & Reliable \\
\hline
\end{tabular}

According to the table above, the Cronbach's Alpha value for all of the variables is more than 0.6 which means these variables are reliable.

\subsection{Classic Assumption Test}

\section{a) Data Normality Test}

In this study, the researcher used P-Plot Graph for data normality test. On this P-Plot Graph below, it can be seen that the dots spread out around the diagonal line and the spread follows the direction of the diagonal line. From this graph it can be concluded that the regression line model fulfills the assumption of normality. 


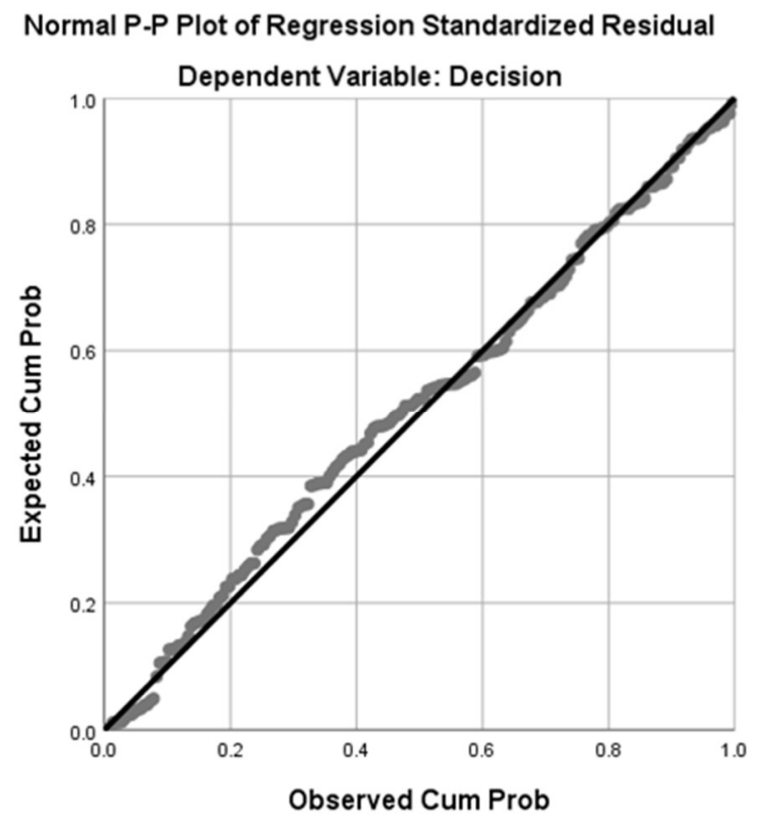

Graph 1

\section{b) Multicollinearity Test}

Multicollinearity testing in this study was carried out by looking at the collinearity statistic and the value of the correlation coefficient between the independent variables. Multicollinearity occurs when the tolerance value $<$ 0.10 and Variance Inflation Factor (VIF) $>10$.

On the table below shows the VIF value for the variable price, promotion, quality and decision to choose less than 10 . While the tolerance value is greater than 0.10 , this indicates that the independent variables in this study do not correlate with each other or there is no correlation between independent variables.

Table 7: Coefficients ${ }^{\mathrm{a}}$

\begin{tabular}{|c|c|c|c|c|c|c|c|c|}
\hline \multirow{2}{*}{\multicolumn{2}{|c|}{ Model }} & \multicolumn{2}{|c|}{ Unstandardized Coefficients } & \multirow{2}{*}{$\begin{array}{c}\text { Standardized } \\
\text { Coefficients } \\
\text { Beta }\end{array}$} & \multirow[b]{2}{*}{$\mathrm{t}$} & \multirow[b]{2}{*}{ Sig. } & \multicolumn{2}{|c|}{$\begin{array}{c}\text { Collinearity } \\
\text { Statistics }\end{array}$} \\
\hline & & B & Std. Error & & & & Tolerance & VIF \\
\hline \multirow[t]{4}{*}{1} & (Constant) & 8.112 & 1.154 & & 7.032 & .000 & & \\
\hline & Price & .107 & .077 & .096 & 1.395 & .165 & .850 & 1.176 \\
\hline & Advertisement & .177 & .050 & .265 & 3.517 & .001 & .716 & 1.396 \\
\hline & Product & .163 & .060 & .204 & 2.727 & .007 & .726 & 1.378 \\
\hline
\end{tabular}

a. Dependent Variable: Decision

\section{c) Heteroscedasticity Test}

An important assumption of the classical linear model is that the errors that appear in the population regression function are homoscedastic, is all errors have the same variance (Gujarati, 1995). One of the methods used to check for heteroscedasticity is with the Scatterplot, under the scattered dots and not above the number 0, and not forming a pattern so that the regression model can be ignored to avoid heteroscedasticity problems. The graph of the Scatterplot is as shown below: 


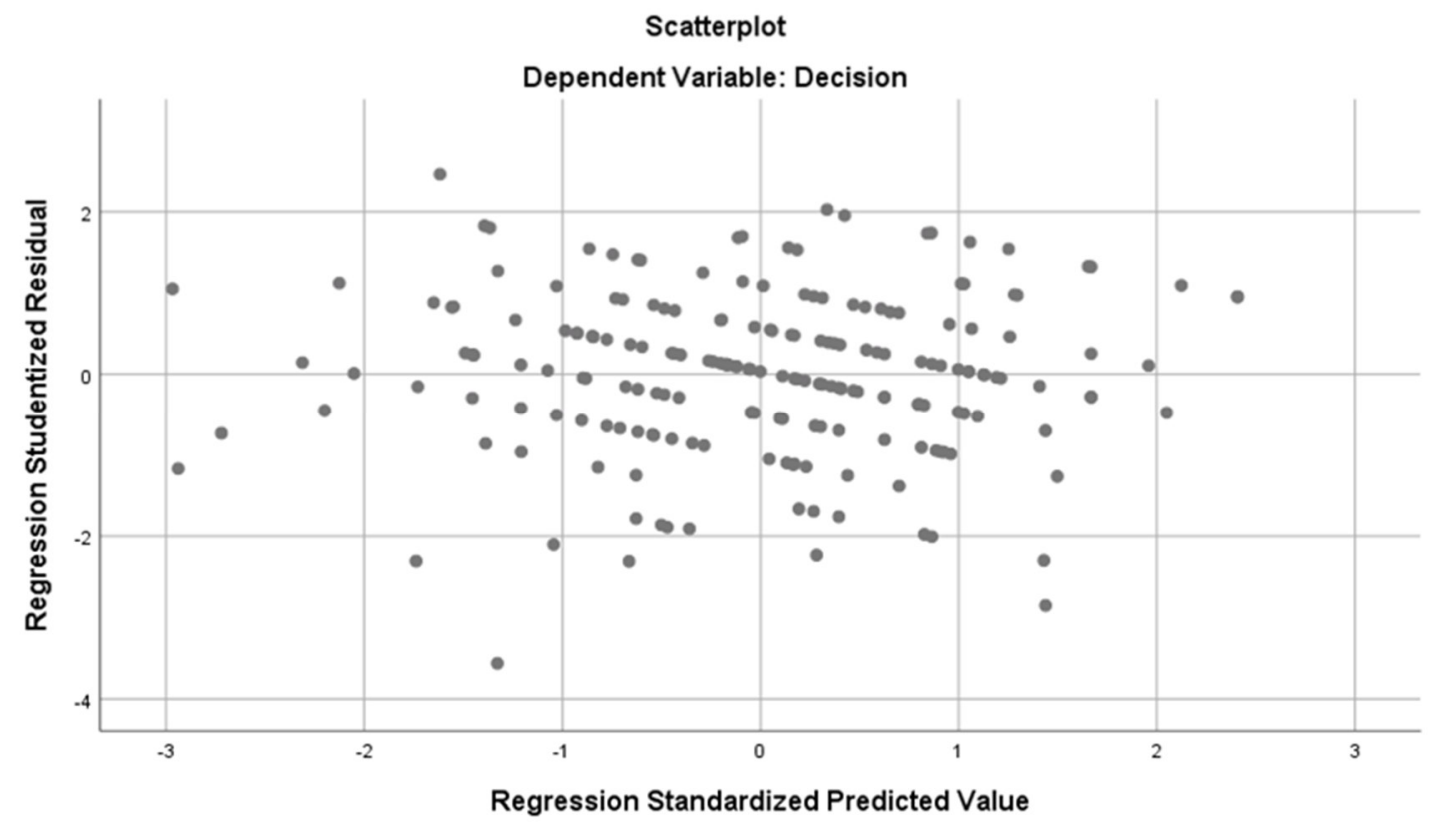

Graph 2

From the SPSS output graph above, clearly shows that the dots spread below and above the number 0 , and do not form a pattern, it can be concluded that in the regression model there is no element of heteroscedasticity.

\subsection{Hypothesis Test}

a) Coefficient Determination (R-test)

The determination test aims to measure how far is the capability of the variation of the independent variables in explaining the variation of the dependent variable in a model.

Table 8: Model Summary ${ }^{\mathrm{b}}$

\begin{tabular}{lr|r|r|r} 
Model & $\mathrm{R}$ & R Square & \multicolumn{1}{c|}{$\begin{array}{c}\text { Adjusted R } \\
\text { Square }\end{array}$} & $\begin{array}{c}\text { Std. Error of the } \\
\text { Estimate }\end{array}$ \\
\hline 1 & $.453^{\mathrm{a}}$ & .205 & .193 & 1.891 \\
\hline
\end{tabular}

a. Predictors: (Constant), Product, Price, Advertisement

\section{b. Dependent Variable: Decision}

From the table above, the value of R Square (R2) that's obtained is 0.205 or $20.5 \%$ which shows the capability of the independent variables in explaining the variation that happened in the decision of buying Indomie, while the remaining $79.5 \%$ is explained by the other variables that are not in the model. The low value of R2 can explain that the capability of the independent variables in explaining the dependent variable is very limited. Ghozali (2005) stated that generally coefficient determination for cross-section data relatively low because of the presence of the big variation between each observation.

b) Partial Test (t-test)

To test the hypothesis of the influence of the variable price, advertisement, and product partially t-test was performed. This test is carried out in two directions, using an alpha significance level of 5\%. 
Table 9: Coefficients ${ }^{\mathrm{a}}$

\begin{tabular}{|c|c|c|c|c|c|c|}
\hline \multirow{2}{*}{\multicolumn{2}{|c|}{ Model }} & \multicolumn{2}{|c|}{ Unstandardized Coefficients } & \multirow{2}{*}{$\begin{array}{l}\text { Standardized } \\
\text { Coefficients } \\
\text { Beta }\end{array}$} & \multirow[b]{2}{*}{$\mathrm{t}$} & \multirow[b]{2}{*}{ Sig. } \\
\hline & & B & Std. Error & & & \\
\hline \multirow[t]{4}{*}{1} & (Constant) & 8.112 & 1.154 & & 7.032 & .000 \\
\hline & Price & .107 & .077 & .096 & 1.395 & .165 \\
\hline & Advertisement & 177 & .050 & .265 & 3.517 & .001 \\
\hline & Product & .163 & .060 & 204 & 2.727 & .007 \\
\hline
\end{tabular}

a. Dependent Variable: Decision

According to the table above, it is known that the constant value is 8.112 and the coefficient value of each variable is 0.107 for $\mathrm{X} 1,0.177$ for $\mathrm{X} 2$, and 0.163 for $\mathrm{X} 3$ respectively, so the regression model for this research is: $\mathrm{Y}=8.112+0.107 \mathrm{X}_{1}+0.177 \mathrm{X}_{2}+0.163 \mathrm{X}_{3}$

where:

$$
\begin{array}{ll}
\mathrm{Y} & =\text { Decision } \\
\mathrm{X}_{1} & =\text { Price } \\
\mathrm{X}_{2} & =\text { Advertisement } \\
\mathrm{X}_{3} & =\text { Product }
\end{array}
$$

From the table above, the result is obtained:

1. The sig value for price variable is 0.165 which is greater than the alpha value 0.05 .

According to the obtained result, $\mathrm{H} 0$ will be accepted and $\mathrm{H} 1$ will be rejected for price variable, which is also mean that price doesn't significantly influence the decision to choose Indomie instant noodle.

2. The sig value for price variable is 0.001 which is less than the alpha value 0.05 .

According to the obtained result, $\mathrm{H} 0$ will be rejected and $\mathrm{H} 1$ will be accepted for advertisement variable, which is also mean that advertisement significantly influences the decision to choose Indomie instant noodle.

3. The sig value for price variable is 0.007 which is less than the alpha value 0.05 .

According to the obtained result, $\mathrm{H} 0$ will be rejected and $\mathrm{H} 1$ will be accepted for product variable, which is also mean that product significantly influences the decision to choose Indomie instant noodle.

\section{c) Simultaneous Test (F-test)}

Similar to t-test hypothesis, to do the F-test hypothesis with the dependent variable (decision) if $F_{\text {count }} \geq F_{\text {table }}$ or Sig. value is less than alpha value $0.05, \mathrm{H} 0$ will be rejected and $\mathrm{H} 1$ will be accepted.

Table 10: NNOVA $^{\mathrm{a}}$

\begin{tabular}{ll|r|r|r|c|c} 
Model & Sum of Squares & df & Mean Square & F & Sig. \\
\hline 1 & Regression & 180.545 & 3 & 60.182 & 16.833 & $.000^{\mathrm{b}}$ \\
\cline { 2 - 8 } & Residual & 700.735 & 196 & 3.575 & & \\
\cline { 2 - 8 } & Total & 881.280 & 199 & & & \\
\hline
\end{tabular}

\section{a. Dependent Variable: Decision}

\section{b. Predictors: (Constant), Product, Price, Advertisement}

From the table above, Sig. value is 0.000 which is less than alpha value 0.05 , hence $\mathrm{H} 0$ will be rejected and $\mathrm{H} 1$ will be accepted, which means the independent variables are able to explain the variation of the dependent variables, which also means the price, advertisement, and product simultaneously influence the purchasing decision of Indomie instant noodle.

\section{Conclusion}

According to the research that has been done above, it can be concluded:

1. Simultaneously, price, advertisement, and product have significant influence on the purchasing decision of Indomie instant noodle

2. Partially, price variable doesn't have significant influence on the purchasing decision of Indomie instant noodle

3. Partially, advertisement variable has significant influence on the purchasing decision of Indomie instant noodle

4. Partially, product variable has significant influence on the purchasing decision of Indomie instant noodle

5. Coefficient Determination (R2) shows the capability of price, advertisement, and product (independent variables) to explain the variation that happened on the purchasing decision at 0.205 or $20.5 \%$, while the 
remaining $79.5 \%$ explained by the other variables that are not stated in this research.

\section{References}

Agung Nugraha, 2014. The Effect of Brand Equity on Purchasing Decisions of Instant Noodle Products (Study on Sedaap Noodles). Journal of the Faculty of Economics, Yogyakarta State University.

Angel, James F., Roger D., Black Well. 2012. Consumer Behavior. Volume 1. Binarupa Aksara, Jakarta Armstrong, Gary \& Philip, Kotler. 2002. Fundamentals of Marketing. Volume 1, Interpreting Alexander

Sindoro and Benjamin Molan. Jakarta: Prenhalindo Publisher.

Basu, Swastha, \& Irawan, 2001, Modern Marketing Management. Yogyakarta Liberty.

Edwarsyah. 2004. Analysis of Consumer Attitudes and Behavior towards Instant Noodle Products. Master Thesis. MM Universitas Budi Luhur. Jakarta.

Fathawati, et al. 2013. Cultural, Social, Personal and Psychological Influences on Purchasing Decisions of Sedaap Noodle Brand Instant Noodles. Management Journal. Islamic University of Malang. Malang, Indonesia.

Ghozali, Imam. 2006. Structural Equation Modeling: Alternative Methods with Partial Least Square. Diponegoro University Publisher Agency: Semarang.

Heriyati, Pantri. 2012. Analysis of the Effect of Brand Image and Product Quality on Consumer Purchasing Decisions on Nexian Mobile Phones. BINUS Business School Journal Jumanto. 50 Indomie Flavor Variants from The Newest to The Best Selling. Catatan Jumanto. https://www.jumanto.com/varian-rasa-indomie/

Kotler, Philip and Armstrong, Gary. 2001. Principles of Marketing (Ninth Edition). New Jersey: Prentice Hall Inc.

Kotler, Philip dan Armstrong. 1997. Marketing Management, Analysis, Planning, Implementation and Control. Jakarta

Kotler, Philip. 1998. Marketing Management: Analysis of Planning for Implementation and Control of Volume 2. Jakarta: PT. Prenhallindo

Kotler, Philip. 2005. Marketing Management. Millennium Edition. Jakarta: PT. Prenhallindo.

Nafali, Mardon and Djurwati Soepeno. 2016. Analysis of the Influence of Consumer Behavior Factors on Purchasing Decisions of Indomie Brand Instant Noodle Food (Case Study on Students of the Faculty of Economics and Business, Faculty of Social and Political Sciences, and Faculty of Agriculture, University of Sam Ratulangi Manado. Journal of EMBA, Sam Ratulangi University. Manado, Indonesia.

Ratriani, Virdita. 2020. The History of Indomie and The Wealth of Its Owner, The Salim Group. Kontan. https://industri.kontan.co.id/news/sejarah-indomie-dan-kekayaan-pemiliknya-salim-group

Schiffman \& Kanuk. 2007. Consumer Behavior (Seventh Edition). Jakarta: PT Index.

Sugiyono 2004. Business Research Methods. Alfabeta, Bandung

Suharno. 2010. Marketing in Practice (First Edition). Jakarta: Mitra Wacana Media

Sulistiani, Sinta. 2017. The Influence of Product Quality and Promotion on Purchasing Decisions that Affect Customer Loyalty in PT Kalbe Farma's Hydro Coco Products. Journal of Education, Law and Business, Pamulang University, Banten.

T.A Hidayati.2013. The Influence of Brand Image on Purchase Interests and Consumer Purchasing Decisions Instant Indomie Brand. Journal of the Faculty of Administrative Sciences, Brawijaya University. 